\title{
Erratum to: Editorial for Special Issue of SPAR: The Vanguard Method in a Systems Thinking Context
}

\section{Brendan O'Donovan}

Published online: 4 January 2014

(C) Springer Science+Business Media New York 2014

\section{Erratum to: Syst Pract Action Res DOI 10.1007/s11213-012-9247-7}

Unfortunately, the article titled 'The application of the vanguard method to enhance resources utilisation in service industries', which is referred in the Editorial, does not appear in this special issue (The Vanguard Method in a Systems Thinking Context), as the article was withdrawn by the author.

The online version of the original article can be found under doi:10.1007/s11213-012-9247-7.

B. O'Donovan $(\bowtie)$

Vanguard Consulting, Buckingham, UK

e-mail: brendan@vanguardconsult.co.uk 